\title{
Validity of RPP based PBL in the social arithmetics
}

\author{
Nunung Septriani ${ }^{1}$, I Made Arnawa ${ }^{2}$, Ermanto Ermanto ${ }^{3}$ \\ ${ }^{123}$ Universitas Negeri Padang, Padang - Indonesia, (krunyung@gmail.com)
}

\begin{abstract}
Problem solving ability is one of the mathematical abilities that are important in the success of students. But the fact remains low problem solving ability. One model that can develop problem solving ability is the Problem Based Learning (PBL). RPP is one important component in learning. RPP used by teachers not specifically describe the learning process, as well as yet to be seen developing students' problem solving abilities. This study aims to determine the validity of PBL based lesson plans. The study consisted of a preliminary analysis phase, development, and assessment using the model of Plomp. However, this study is only done up to the stage of development that the validity of the stage. The instrument used in this study of guidance interviews, checklists, questionnaires, evaluation sheets and sheets validas experts themselves. The results of the validation sheet analysis showed RPP developed are valid with an average of validity index of 0.96 .
\end{abstract}

Keywords: validity, rpp, pbl, social arithmetic.

\section{Introduction}

Mathematics is one of the basic science has always studied at every level of education, from primary education to higher education. Mathematics as one requirement subjects in graduate students. Mathematics is also the basic knowledge needed to support student success. it does show that mathematics has an important role in education. In mathematics there are five aspects of the standard capabilities that must be owned by the students, the ability of problem solving (problem solving), reasoning (reasoning), communication skills (communication), the ability of the connection (connection), and the ability of representation (representation) (NCTM: 2000).

Problem solving ability is one of the mathematical ability has an important role in the success achieved by students. problem solving ability has been the main focus of the reform of mathematics education for more than 20 years (Rickard: 2005). The same thing also described Launcher (Wardani, et al: 2010), "problem solving is a skill that needs to be taught, and teachers must make an effort for it". But the fact that occur in the field is different, many teachers still have difficulty implementing the learning activities that students have problem-solving abilities, siswapun many difficulties in solving the problems of mathematics (Krismanto \& Wibawa: 2010).

Things are not much different from the author found in the field when carrying out observations in SMPS Naga Sakti Tapung Hilir Subdistrict Kampar regency. Students have difficulty when administered about higher-order thinking such as problem solving. Often students can not 
understand the issues well, so that students can not plan for the settlement of the problem appropriately. Therefore, solutions to problems by the students is also inaccurate.

Learning mathematics implemented in the business class has not emphasized students construct knowledge. Learning is still dominated by the teacher with the lesson is a step-by-step routine, such as: the teacher gives the concept with sample questions, students do exercises similar to the example provided by the teacher, the students do the exercises contained in the student worksheet (LKS). At the time of the learning process, it appears that teachers do not get used to learning which presents problems of solving the problem. Teachers are still not utilizing problem-solving ability as a target to be achieved by students in learning.

When given a test question to see the problem-solving abilities, are still a few students were able to solve the problems properly. This shows that the mathematical problem solving ability of students is still low and needs to be improved. To overcome these problems, we need a model of learning characteristics and learning steps can membelajarkan students' mathematical problem solving ability. One model of learning suited to address the problems found in the field is Problem Based Learning (PBL).

Problem Based Learning (PBL) is a learning that encourages a deeper understanding of the material and also a problem-based learning where students not only get the basic knowledge but also the experience when learning how to use their knowledge to solve real-world problems (Bilgin: 2009). Problem Based Learning (PBL) aims to enable students gain experience through autonomous, independent learning, inquisition and problem solving skills, which individuals are faced with such situations they face in everyday life and was pushed to learn individually through self-study and research (Karaduman: 2013).

One material that is in the process of mastery requires problem-solving ability is a social arithmetic. Material social arithmetic is one of the materials on the standard class VII student competency. This material needs to be studied to develop the students' ability to solve the problems of everyday life, especially in activities perekonomnian (trade). Learning social arithmetic should be done constructively in accordance with the learning paradigm shift today. Problem-based Learning (PBL) is an instructional model that is based on constructivist learning theory. Thus the material relevant social arithmetic taught to Problem Based Learning (PBL).

Learning in the classroom implementation basically requires a learning device for its operation. Model and learning devices are the two things are interrelated and difficult to separate. A model requires a device and vice versa in developing the device requires a model of learning that will inform the development of these devices.

Learning instrument is an important part of a learning process. As for the reason of the importance of a learning device according to Wahyudi (2014), namely (1) to guide learning, (2) as a minimum standard of teacher performance, (3) improving teacher performance, and (4) teacher performance evaluation tool. The importance of Learning instrument show that before learning need to be prepared a learning device that support the learning process, because the learning device can affect the quality of teaching and learning quality is closely related to the quality of education. In addition, the device also acts to facilitate students in the achievement of competencies and learning objectives.

Before teaching a teacher is expected to prepare the material that will be taught, preparing props or lab to be used, prepare questions and referrals to lure students more active in learning, studying the situation of students, all of this will unravel in the implementation of Learning instrument. For the implementation of the necessary learning Learning Implementation Plan (RPP) should be adapted to the context of life faced by students and strived to facilitate students in revealing the capacity to think.

Every teacher in the educational unit is obliged to draw up a complete lesson plan and systematically so that learning takes place in an interactive, inspiring, fun, challenging, motivating the 
students to actively participate and provide enough space for the physical and psychological development of learners. This suggests that teachers must prepare lesson plans as a learning plan tailored to students' needs and objectives to be achieved.

But the reality in the field, based on our analysis of the RPP compiled and used by the teachers still found some weaknesses. RPP used by teachers already using a model or approach to learning but the steps and learning activities not specifically describe the learning process on the content being taught. The RPP has not been reflected on the activities that enable students, as well as yet to be seen helping develop students' mathematical problem solving ability. In other words, RPP compiled the teacher has not conditioned by the needs of students. RPP has not arranged a special attention to the students' characteristics and goals to be achieved.

Based on the explanation above, it is necessary to describe specific lesson plan learning activities in accordance material being taught, can develop students' mathematical problem solving ability, and in accordance with the needs of students. Furthermore, the RPP will also be used by the teacher in the learning process. To that made the development of lesson plans based on Problem Based Learning (PBL). The purpose of this study was conducted to determine the validity of the RPP-based Problem Based Learning (PBL).

\section{Method}

The study is a research \& development (Research and development). The model used is a model development Plomp which consists of three phases, namely: a preliminary analysis phase, phase of development or manufacture of prototypes and assessment phase. In the phase of the preliminary analysis carried out a needs analysis, curriculum analysis, concept analysis, and analysis of the students. The results of the preliminary analysis phase of analysis used as the basis for development PBL based lesson plans. In the prototype phase of development or manufacture to design lesson plans, evaluation and revision of the prototype through formative evaluation stages comprising its own evaluation, assessment specialists or experts, individual evaluation, and the evaluation of the small group. Later in the assessment phase conducted field tests to look at the practicalities and effectiveness.

This study is only done through development or prototype namely the validity stage. Because the goal of this study to determine the validity of the RPP-based Problem Based Learning (PBL). Instruments used in this study is guideline interviews, checklists, questionnaires, evaluation sheets and sheets validas experts themselves. Before use, each instrument validated by experts. The instrument has a valid used in the study. Data the results were analyzed according to the type of data. The qualitative data were analyzed by Qualitative and quantitative data were analyzed and categorized so it can be taken qualitative conclusions.

\section{Results and Discussion}

\section{Preliminary Analysis Phase (Preliminary Research)}

Activity this preliminary analysis into the early stages of research. The activities undertaken preliminary analysis is activity needs analysis, curriculum analysis, concept analysis, and analysis of the students. Based on the results of a needs analysis obtained information that the learning process is carried out is still dominated by teachers, learning steps are executed is a step-by-step routine, such as: the teacher gives the concept with examples of problems, and then the students do exercises similar to the questions that have been awarded the teacher. Teachers do not get used to learning presents problems to train the students problem solving abilities. So that students have difficulty when faced with the problem solving. 
RPP used in the study has used a model or approach, but has not specifically describe the learning steps on the content being taught. RPP has not been reflected on the activities that enable students, as well as yet to be seen membelajarkan students' problem-solving abilities. In other words RPP compiled the teacher has not conditioned by the needs of students.

Information obtained next is the students' understanding of the material that has been studied. According to teachers, the ability of the students are very diverse, students' understanding of the material depends on the interest and attention to them during the learning process. There are still many students who think math is difficult because many of the formulas used. According to the teachers, most students can not understand the material very well, but they did not dare to ask about the subject matter that is less understood because they feel embarrassed and scared one to ask questions.

At this stage of the study carried out anaisis curriculum education unit level curriculum that apply in school mathematics courses class VII. Based on the results of analysis show that there are five items in the first half that number, algebra, linear equations and inequalities of one variable, social arithmetic, and comparison. The material for the development of the RPP in this study is a matter of social arithmetic. The material selected for the material arithmetic is very useful in everyday life, especially in trading activities (economic). Social Arithmetic material is suitable to be implemented with problem based learning (PBL).

At the stage of concept analysis carried out activities to identify the main concepts that are taught, detailing, and arranged systematically. The materials are arranged hierarchically with the main subject is arithmetic sub-material social and overall value, the value per unit, the most value, profit, loss, rebates (discounts), gross, tare, and net, as well as single flowers and taxes.

Student questionnaire data analysis shows that students think math lessons that are useful in everyday life, but students mengelami difficulty in understanding the material and solve problems in the form of word problems. Students are more like group learning system, and more likely to ask friends if it does not understand the subject matter. Based on the results of the preliminary analysis, the researchers found it necessary to develop lesson plans that can support learning activities that can make students active and facilitate students to improve their abilities, especially the ability of problem solving.

\section{The development phase or Manufacture Prototype (Prototyping Stage)}

1. Design-based RPP Problem Based Learning (PBL)

Based on a preliminary analysis, designed Learning Implementation Plan (RPP) based on Problem Based Learning (PBL) in the matter of social arithmetic. RPP is designed based on the characteristics and stages based Problem Based Learning (PBL). RPP systematically designed with attention to the linkages and coherence between SK, KD, indicators of achievement of competencies, learning objectives, teaching materials, teaching methods, learning resources, learning activities, and assessment.

Step-by-step instructional activities in the lesson plan, it consists of introductory, core activities, and closing activities. In the preliminary events are open lesson activities, preparing condition both physically and psychologically students to learn, apperception, motivation, and the phases based learning Problem Based Learning (PBL) will be implemented. Core activities presented in the RPP refers based learning Problem Based Learning (PBL), which contains five phases mgorientasi students on the issue, organizing students to learn, guiding the investigations of individuals or groups, develop and present the work, and to analyze and evaluate the problem solving process, In closing activities are concluded activities and directing student learning materials for learning the next meeting. 
2. Self Evaluation

Before discuss lesson plans that have been designed to the experts, conducted its own evaluation. Some aspects of the evaluation include typing errors, correct use of words and terms, correct use of punctuation, and accuracy with step RPP activities Problem Based Learning (PBL). After the evaluation itself, discovered several errors contained in the RPP based PBL. Further improvement against the RPP.

3. RPP based validation Problem Based Learning (PBL) by experts

RPP who have designed and evaluated its own further validation. This validation is carried out competent experts in their respective fields. Validation RPP conducted by three experts, consisting of two experts in mathematics and one Indonesian expert. During the process of validation of RPP, there are several revisions implemented based on suggestions from the validator. Having seen various inputs and suggestions from the validator, carried out repairs on the PBL-based lesson plans.

Suggestions validator which are associated with penuliasn teaching materials, there is some material that was suggested to be eliminated. Then the researchers improve the RPP based on advice from the validator. Overall RPP based Problem Based Learning (PBL) developed already valid criteria with an average of validity index of 0.96 . Thus, it can be concluded that the RPP based on Problem Based Learning (PBL) on the social arithmetic material have a valid.

\section{Conclusions}

Based on the stages of development that have been implemented, the obtained results the in form of RPP-based Problem Based Learning (PBL) in social arithmetic material that has been developed valid.Berdasarkan research has been carried out, it can be recommended based math learning tool Problem Based Learning (PBL) on the material social arithmetic class VII developed the first half was valid, there was expected to further testing at other schools to look at the practicalities and effectiveness of a wider range of lesson plans based on Problem based Learning (PBL) were developed.

\section{Acknowledgments}

The researchers wish to thank all those who have helped make this research can be resolved properly. Thank you for your guidance, advice, and guidance of lecturers and professors validator. Thank you for your permission and cooperation in conducting research from a large family of SMPS Naga Sakti Tapung Hilir Subdistrict Kampar regency.

\section{References}

Bilgin, Ibrahim. (2009). The effects of Problem Based Learning Intruction on University Student' Performance of Conceptual and Quantitative Problems in Gas Conceps. Eurasia Journal of Mathematics, Science \& Technology Education. 5(2): 153-156.

Karaduman. (2013). The Relationship Between Prospective Primary Mathematics Teachers' Attitudes Towards Problem-Based Learning And Their Studying Tendencies. International Journal on New Trends in Education and Their Implications. Volume: 4 (13): 145-151.

Krismanto, A. \& Wibawa, A.D. (2010). Pembelajaran Kemampuan Pemecahan Masalah Bangun Datar di $S M P$. Kementerian Pendidikan Nasional. Pusat Pengembangan dan Pemberdayaan Pendidik dan Tenaga Kependidikan (PPPPTK) Matematika. 
National Council of Teachers of Mathematics. (2000). Principle and Standard for School Mathematics. Reston: NCTM.

Plomp, T dan N. Nieveen. (2013). Educational Design Research. Enshede: SLO.

Wahyudi, I. (2014). Panduan Lengkap Administrasi Mengajar Guru. Jakarta: Prestasi Pustaka. 